\title{
INTERVENSI KESEHATAN WASPADA DEMAM BERDARAH (DBD) DI KELURAHAN TURIDA TAHUN 2017
}

\author{
Diani Sri Hidayati*, Nisia Putri Rinayu** \\ Fakultas Kedokteran Universitas Islam Al-Azhar \\ J1. Unizar No.20 Turida Mataram \\ dianihidayati@yahoo.com
}

\begin{abstract}
ABSTRAK
Perubahan musim yang ekstrim dapat memicu timbul dan berkembangnya berbagai macam penyakit yang mungkin dapat menjadi wabah berbahaya bagi masyarakat. Musim hujan menyuburkan datangnya jentik-jentik nyamuk yang menjadi sumber penyakit bila keadaan lingkungan tidak terjaga dengan baik, seperti pada sisi kebersihan serta kerapian lingkungannya. Diperlukan adanya suatu usaha penyadaran masyarakat tentang bahaya penyakit DBD.

Usaha-usaha yang dapat dilakukan adalah yang bersifat aktif dan persuasive guna mengajak bersama masyarakat untuk memerangi sertamen cegah penyebaran penyakit DBD untuk meningkatkan pengetahuan dan kesadaran masyarakat KelurahanTurida dalam upaya mencegah penyakit DBD, meningkatkan kepedulian masyarakat terhadap pentingnya kegiatan pencegahan DBD, dan memberikan pengetahuan dan pemahaman yang benar tentang DBD. Metodenya adalah "Waspada DBD“. Bentuk kegiatan yang dilakukan ada tiga, yaitu; penyuluhan, pembagian abate dan program PJB (PemantauanJentikBerkala), dan pemasangan poster.

Hasil penyuluhan dihadiri oleh masyarakat Turida dari lima lingkungan yang berjumlah 56 orang. Dalam penyuluhan ini dipaparkan tanda dan gejala DBD,cara pencegahan, kegunaan abate juga memberi sosialisasi cara mengisi kartu jumantik untuk setiap KK. Pembagian Abate dan Program PJB (Pemantauan Jentik Berkala). Program PJB dan pembagian abate ini dilakukan bersamaan untuk tiga lingkungan yaitu Turida Barat Turida Timur dan Lendang Lekong. Poster dipasang di pertengahan lingkungan Turida Barat danTuridaTimur juga di lingkungan Lendang Lekong. Penelitian ini kurang maksimal karena di hadiri oleh 56 warga sehingga belum dapat mewakili populasi Kelurahan Turida selain itu tidak diketahui tingkat efektifitas penyuluhan terhadap pengetahuan masyrakat.
\end{abstract}

Keyword : Demam berdarah, Turida, Penyuluhan, pemasangan poster.

\section{PENDAHULUAN}

Perubahan musim yang drastis serta keadaan lingkungan yang ada pada masyarakat dapat memicu timbul dan berkembangnya berbagai macam penyakit yang mungkin dapat menjadi wabah yang berbahaya bagi masyarakat. Musim hujan menjadi musim yang subur akan datangnya jentik-jentik nyamuk yang menjadi sumber penyakit bila keadaan lingkungan tidak terjaga dengan baik, seperti pada sisi kebersihan serta kerapian lingkungannya.

Keadaan yang terjadi, selama musim hujan datang, masyarakat senantiasa waspada akan timbulnya berbagai macam penyakit yang sudah umum menjadi wabah. Kegiatan yang preventif untuk mencegah tambah luasnya wabah penyakit yang dapat ditimbulkan, warga masyarakat khususnya warga masyarakat Kelurahan Turida melakukan kegiatan Penataan Lingkungan guna mengurangi adanya perkembangbiakan benih-benih penyakit yang mungkin dibawa seiring datangnya musim hujan.

Wabah penyakit yang umum terjadi dengan datangnya musim hujan adalah Demam Berdarah Dengue (DBD). Penyakit ini menjadi jenis penyakit yang 
sering menimbulkan keresahan bagi masyarakat, mengingat dampaknya yang dapat menimbulkan kematian bagi penderita jika tidak ditangani dengan segera dan benar. Penyakit DBD menyebar melalui gigitan nyamuk. Secara umum, dengan datangnya musim hujan, maka sangat dimungkinkan banyaknya genangan air yang tersisa dari hujan yang ada.

Genangan-genangan air yang semacam ini menjadi tempat utama perkembangbiakan jentik-jentik serta benih-benih nyamuk yang nantinya akan berkembang menjadi nyamuk dewasa yang dapat menyebarkan penyakit DBD. Di samping itu, kebiasaan masyarakat yang membuang sampah di sembarang tempat akan semakin menambah kemungkinan bertambahnya sarang nyamuk yang dapat menyebabkan semakin berkembangnya jumlah benih bahkan nyamuk dewasa yang dapat menyebarkan penyakit ini.

Oleh karena itu diperlukan adanya suatu usaha penyadaran masyarakat tentang berbahanya penyakit DBD. Usaha-usaha yang dapat dilakukan adalah yang bersifat aktif dan persuasif guna mengajak bersama masyarakat untuk memerangi serta mencegah penyebaran penyakit DBD. Kegiatan Penyuluhan Kesehatan tentang pencegahan penyakit DBD menjadi satu program Penyuluhan dari Tim Pengabdian Kepada Masyarakat
Fakultas Kedokteran Universitas Islam Al-Azhar yang memiliki tujuan untuk memberikan pemahaman kepada masyarakat Kelurahan Turida tentang cara-cara atau langkah-langkah pencegahan Penyakit DBD. Kegiatan ini merupakan satu bentuk kepedulian Fakultas Kedokteran Universitas Islam Al-Azhar terhadap semakin berkembangnya penyakit DBD seiring dengan datangnya musim penghujan.

\section{METODE INTERVENSI}

\section{Tema dan Bentuk Kegiatan}

Adapun tema dari kegiatan Intervensi kesehatan kali ini yaitu "Waspada DBD“. Bentuk kegiatan yang dilakukan ada tiga, yaitu; penyuluhan, pembagian abate dan program PJB (Pemantauan Jentik Berkala), dan pemasangan poster. Pada kegiatan penyuluhan dipaparkan tanda dan gejala DBD, cara pencegahan, kegunaan abate juga memberi sosialisasi cara mengisi kartu jumantik untuk setiap KK, kemudian dilanjutkan dengan diskusi dan tanya jawab.

\section{Pembagian Abate dan PJB serta} pemasangan poster merupakan wujud dari realisasi dari penyuluhan DBD agar masyarakat lebih mengerti cara mencegah dari penyakit DBD itu sendiri. Spanduk di pasang di pertengahan Lingkungan Turida Barat dan Turida Timur juga di lingkungan Lendang Lekong. 


\section{Tujuan Kegiatan}

Adapun tujuan dari intervensi ini adalah untuk meningkatkan pengetahuan dan kesadaran masyarakat Kelurahan Turida dalam upaya mencegah penyakit DBD, meningkatkan kepedulian masyarakat terhadap pentingnya kegiatan pencegahan DBD, dan memberikan pengetahuan dan pemahaman yang benar tentang DBD.

\section{Sasaran Kegiatan}

Sasaran dari intervensi ini adalah masyarakat di Kelurahan Turida di 3 Lingkungan.

\section{Target Kegiatan.}

Melalui kegiatan penyuluhan kesehatan mengenai DBD, masyarakat yang ada di kelurahan Turida mendapatkan informasi tentang pencegahan DBD sehingga dapat mengaplikasinnya dalam kehidupan sehari-hari.

Waktu dan Tempat Pelaksanaan Kegiatan

Waktu pelaksanaan intervensi adalah pada hari Sabtu, tanggal 12 Agustus 2017 pukul 16.00 WITA- selesai, di Lingkungan Lendang Lekong Kelurahan Turida.

\section{HASIL KEGIATAN}

\section{Penyuluhan Waspada DBD}

Penyuluhan dilaksanakan pada hari Sabtu, 12 Agustus 2017 di Masjid As'salam. Penyuluhan ini dihadiri oleh masyarakat Turida dari lima lingkungan yang berjumlah 56 orang. Dalam penyuluhan ini dipaparkan tanda dan gejala DBD,cara pencegahan,kegunaan abate juga memberi sosialisasi cara mengisi kartu jumantik untuk setiap KK.

Pembagian Abate dan Program PJB (Pemantauan Jentik Berkala)

Kegiatan ini dilaksanakan tiga hari secara bertahap yaitu tanggal 9 Agustus 2017- 11 Agustus 2017. Program PJB dan pembagian abate ini dilakukan bersamaan untuk tiga lingkungan yaitu Turida Barat,Turida Timur dan Lendang Lekong

\section{Pemasangan Poster}

Pemasangan poster dilakukan pada hari Rabu,16 Agustus 2017. Poster dipasang di pertengahan lingkungan Turida Barat dan Turida Timur juga di lingkungan Lendang Lekong

\section{KESIMPULAN}

Kegiatan intervensi berupa penyuluhan kesehatan tentang DBD pada hari Sabtu, 12 Agustus 2017 di Lingkungan Lendang Lekong Kelurahan Turida telah berjalan dengan lancer. Penyampaian materi dan proses tanya jawab berlangsung lancar, namun kurang maksimal karena hanya ada 56 warga yang datang menghadiri penyuluhan. Angka ini dirasa belum dapat mewakili populasi Kelurahan Turida. Selain itu, tidak dilakukannya pendataan tingkat pengetahuan ulang pada masyarakat yang 
datang menyebabkan tidak diketahuinya tingkat efektifitas penyuluhan terhadap pengetahuan masyarakat.

\section{DAFTAR PUSTAKA}

Depkes RI. Gerakan Indonesia Cinta Sehat Pembangunan Kesehatan dengan Upaya PromotivePreventive dengan Tidak.

Depkes RI. Indonesia Prakarsai Pengendalian DBD di Asean. Diakses pada tanggal 08 Agustus 2017 dari URL http://www.depkes.go.id/index.php /berita/pressrelease/1542indonesia-prakarsaipengendalian-dbd-di-asean.html.

Depkes RI. Kampanye "Tepat Tangani Demam Melalui Pelatihan Kader Jumantik" sebagai Wujud Kerjasama Kementerian Kesehatan RI dan Glaxosmithkline dalam Upaya Turunkan Kasus DBD diakses pada tanggal 08 Agustus 2017 dari URL http://www.depkes.go.id/index.php /berita/press-

release/1539kampanye-ayo-stopdbd-peran-serta-masyarakat-dalamupayamemberantas-dbd.html.

Depkes RI. Pemberantasan Demam Berdarah Membutuhkan Komitmen Semua Pihak. diakses pada tanggal 10 Agustus 2017 WIB dari URL http://www.depkes.go.id/index.ph p/berita/pressrelease/1547pemberantasan-demam-berdarahmembutuhkankomitmen-semuapihak.html.

Hadinegoro Sri Rejeki. Demam Berdarah Dengue. Jakarta: Fakultas Kedokteran Universitas Indonesia. 2004.

Hardiyanti, W., Mulyani, A., Daryono. Analisis Perilaku Masyarakat.
Hidayat, Ahmad Nur. Tingkat Pengetahuan, Sikap dan Praktek Keluarga Tentang Pencegahan DBD di Rw 09 Kelurahan Kramatpela Kecamatan Kebayoran Baru Jakarta Selatan Tahun 2009. (SKRIPSI). Jakarta: FKIK UIN Syarif Hidayatullah. 2009.

Mafazi, Muhammad Atras. Tingkat Pengetahuan, Sikap dan Perilaku Siswa SD Kelas 4-6 Terhadap Penyakit Demam Berdarah Dengue dan Pencegahannya di SD Islam Ruhama Tahun 2011. (SKRIPSI). Jakarta: FKIK UIN Syarif Hidayatullah. 2011.

Mardiana Ratna. Panduan Lengkap Kesehatan: Mengenal, Mencegah dan Mengobati Penularan Penyakit dari Infeksi. Yogjakarta: Citra Pustaka. 2010.

Notoatmodjo Soekidjo. Kesehatan Masyarakat Ilmu dan Seni. Jakarta: Rineka Cipta. 2007.

Notoatmodjo Soekidjo. Promosi Kesehatan \& Ilmu Perilaku. Jakarta: Rineka Cipta. 2007.

Pangemanan Jane., Nelwan Jeini. Perilaku Masyarakat Tentang Program Pemberantasan Penyakit DBD di Kabupaten Minahasa Utara. Jurnal Kesehatan Masyarakat. Vol. 1 (1), h. 45- 50. 2012.

Terhadap Angka Bebas Jentik dan Demam Berdarah di Kecamatan Pekanbaru Kota Riau. Jurnal Ilmu Lingkungan Vol. 5 (1). 2011.

Who. Dengue and severe dengue. Diakses pada tanggal 10 Agustus 2017 dari URL

http://www.who.int/mediacentre/fa ctsheets/fs117/en/.

Widoyono. Penyakit Tropis; Epidemiologi, Penularan, Pencegahan \& Pemberantasannya. Jakarta: Erlangga. 2008. 